\title{
Responses in the voluntary intake of hay or silage by lactating cows to intraruminal infusions of sodium acetate or sodium propionate, the tonicity of rumen fluid or rumen distension
}

\author{
BY M. H. ANIL*, J. N. MBANYA†, H. W. SYMONDS AND J. M. FORBESł \\ Department of Animal Physiology and Nutrition, University of Leeds, Leeds LS2 $9 J T$
}

(Received 7 February 1991 - Accepted 29 October 1992)

\begin{abstract}
Rumen-fistulated lactating cows were individually fed on hay or silage and intakes were monitored during $3 \mathrm{~h}$ treatment periods and for $\mathbf{2 h}$ after. Each experiment used five, six or seven animals and the treatments were applied in a Latin Square design. Sodium acetate infusions of 1.8-11.0 mol in 4.5 litres water caused a dose-related depression in hay intake, the extent being $82 \mathrm{~g}$ dry matter (DM)/mol infused $(P<0.01)$. Sodium acetate infusions of $6.0-15.0 \mathrm{~mol}$ in 4.5 litres water caused a dose-related depression in silage intake of $118 \mathrm{~g} \mathrm{DM} / \mathrm{mol}$ infused. Rumen fluid $\mathrm{pH}$ for both diets was unaffected by treatment. Acetate and $\mathrm{Na}$ concentrations were increased and significantly negatively correlated with intake of both diets. Infusions of 2-8 mol sodium propionate caused a dose-related depression of hay intake which was significant when cow and day effects were accounted for. Sodium propionate infusions of 4-8 mol significantly depressed silage intake by $140 \mathrm{~g} \mathrm{DM} / \mathrm{mol}$ infused $(P<0.001)$. Rumen fluid pH was unaffected by treatment while propionate and $\mathrm{Na}$ concentrations were elevated and significantly negatively correlated with intake for both diets. Inflation of a rubber balloon in the rumen with 12.5-20 litres warm water resulted in a dose-dependent depression in hay intake of $66 \mathrm{~g} \mathrm{DM} / 1$ distension $(P<0$-05). There was significant overeating during the $2 \mathrm{~h}$ following the 20 litre treatment. With silage, 15-25 litres of balloon distension for $3 \mathrm{~h}$ resulted in a dose-dependent depression in intake of $28 \mathrm{~g} \mathrm{DM} / 1$ distension $(P<0$-001). There was no significant overeating during the $2 \mathrm{~h}$ following distension. When given in physiological amounts, at the lower end of the range used in these experiments, acetate, propionate and distension of the rumen did not significantly affect hay intakes. However, in each case the linear relationship between intake depression and level of treatment suggested that these factors could contribute to the control of feed intake.
\end{abstract}

Voluntary intake: Silage: Hay: Volatile fatty acids: Dairy cows

It is apparent that various feedback signals which arise in different parts of the viscera as a result of consuming meals affect intake-controlling circuits in the brain and it is likely that these signals act together to control feeding. Some of the important factors which might be involved in ruminant animals, particularly in the short-term control of food intake, are: distension of the rumen (Balch \& Campling, 1962), acetate in the rumen (Baile \& Mayer, 1969), lactate in the duodenum (Bueno, 1975), propionate in the liver (Anil \& Forbes, 1980) and heat in the abdomen (Gengler et al. 1970). Considerable doubt has been expressed about the specificity of the effects of infusing salts of VFA, however, in view of the fact that they elevate the osmolality of rumen fluid to an unnatural degree sufficient to depress food intake irrespective of any direct effect of the acids (e.g. Carter \& Grovum, 1988).

Grass is the most important source of forage for ruminant production systems in the UK and its conservation as silage has been of increasing importance in recent years. The

* Present address: Department of Meat Science, University of Bristol, Langford, Bristol BS18 7DY.

$\dagger$ Present address: Institute of Animal Research, Bambui, Cameroon.

\$ For reprints. 
voluntary consumption of silage has been reported to be lower than that of the same crop fed fresh or as hay (Moore et al. 1960; Gordon et al. 1961) and this has been variously associated with the presence of high contents of water (Dodsworth, 1954), amines (Neumark et al. 1964), organic acids (McLeod et al. 1970), the slow removal of digesta from the rumen of animals fed on silage (Campling, 1964) and insufficient protein (Castle, 1983). Infusion of silage extract into the rumen depressed food intake in sheep (Clancy et al. 1977; Phillip et al. 1981) and cattle (Thomas et al. 1961) but there appear to have been no studies of the effects of VFA on silage intake by dairy cattle, and little work on the physical limitation of intake of this feed by distension of the reticulo-rumen. Farhan $\&$ Thomas (1978) distended the rumen of dry cows with 8 litres water in plastic bags over $12 \mathrm{~d}$ and observed a mean reduction in silage dry matter (DM) intake of $1.9 \% / 1$ distension.

The experiments reported here were carried out to ascertain how hay or silage intakes by lactating cows were affected by rumen treatments of a range of doses of acetate, sodium propionate or distension. Some of this work has been briefly reported elsewhere (Anil et al. 1987, 1989; Mbanya et al. 1987, 1988).

\section{MATERIALS AND METHODS \\ Animals}

Seven Friesian cows late in their third or fourth pregnancies were prepared with chronic rumen fistulas. The experiments were conducted after calving at different stages of lactation and pregnancy as the cows became pregnant again by artificial insemination within 3 months of the start of lactation. In Expts 1a, $2 a$ and $3 a$ the cows were in their 3rd and 4th lactations while for Expts $1 b, 2 b$ and $3 b$ they were in their 4th and 5th lactations. the animals were tethered in individual stalls but allowed to exercise for at least $1 \mathrm{~h} / \mathrm{d}$ in a yard.

\section{Surgical preparation}

A rumen fistula was prepared in a one-stage operation, suturing the rumen wall to the skin under regional analgesia using a paravertebral block and sedation with Xylazine (Rompun; Bayer AG, Bury St Edmunds, Suffolk). The cannulas used were made of silicone rubber and had a centre hole of $100 \mathrm{~mm}$ diameter (Bar Dimond Inc., Parma, ID, USA); the manufacturers' instructions were followed in performing the operation.

The cows were given a pain-reliever (Tomanol; Intervet, Cambridge) for 1 week following surgery.

\section{Feeding}

When hay was fed it was coarsely chopped ryegrass (Lolium perenne L.) hay from the same batch throughout (Table 1) and was available continuously. Silage was made from a ryegrass sward and was from a different batch for each experiment. Both forages were fed ad lib. to give $15 \%$ refusals. A compound feed mix containing $(\mathrm{g} / \mathrm{kg})$ barley 510 , dried sugar-beet pulp 170, maize gluten 192 , soya-bean meal 65 , minerals 21 , fodder beans 42 , was fed at $8 \mathrm{~kg} / \mathrm{d}$ in Expts $\mathrm{lb}$ and $2 \mathrm{~b}$. Molassed sugar-beet pulp was fed at $3 \mathrm{~kg} / \mathrm{d}(2 \mathrm{~kg} / \mathrm{d}$ in Expt la and none in Expt 3b). The proximate analysis of the feeds is shown in Table 1.

During the exercise period the forage was provided in a rack thus precluding the measurement of daily intakes. Drinking water and salt licks were continuously available.

\section{Analytical methods}

Feeds were analysed according to the methods described by the Ministry of Agriculture Fisheries and Food (1986); silage DM was determined by toluene distillation. VFA levels in rumen fluid were determined by GLC. 
Table 1. Mean composition of feeds analysed according to the methods of the Ministry of Agriculture, Fisheries and Food (1986)

\begin{tabular}{|c|c|c|c|c|c|c|c|}
\hline \multirow[t]{2}{*}{ Expt ... } & \multicolumn{3}{|c|}{$1 \mathrm{a}, 2 \mathrm{a}$ and $3 \mathrm{a}$} & \multirow{2}{*}{$\begin{array}{l}1 \mathrm{~b}, 2 \mathrm{~b} \text { and } 3 \mathrm{~b} \\
\text { Concentrate }\end{array}$} & $1 b$ & \multirow{2}{*}{$\frac{2 b}{\text { Silage }}$} & \multirow[t]{2}{*}{$3 b$} \\
\hline & Hay & SBP & Concentrate & & & & \\
\hline No. of samples & 10 & 5 & 5 & 5 & 5 & 5 & 5 \\
\hline Dry matter $(\mathrm{g} / \mathrm{kg})$ & 906 & 909 & 883 & 878 & 236 & 229 & 227 \\
\hline $\begin{array}{l}\text { Modified acid-detergent fibre } \\
\text { (g/kg DM) }\end{array}$ & 386 & 152 & 98 & 106 & 368 & 349 & 361 \\
\hline $\begin{array}{l}\text { Diethyl ether extract } \\
\text { (g/kg DM) }\end{array}$ & 25 & 11 & 21 & - & 62 & 42 & 63 \\
\hline $\begin{array}{l}\text { Crude protein } \\
\mathrm{N} \times 6.25 ; \mathrm{g} / \mathrm{kg} \mathrm{DM})\end{array}$ & 138 & 103 & 167 & 200 & 151 & 158 & 148 \\
\hline Ash $(g / k g ~ D M)$ & 47 & & & 43 & & & \\
\hline Ammonia- $\mathrm{N}(\mathrm{g} / \mathrm{kg}$ total $\mathrm{N})$ & & & & & 81 & 74 & 69 \\
\hline $\mathrm{pH}$ & & & & & $3 \cdot 8$ & $4 \cdot 0$ & $3 \cdot 8$ \\
\hline Calculated ME (MJ/kg DM) & & & & & $9 \cdot 8$ & $10 \cdot 0$ & $10 \cdot 0$ \\
\hline
\end{tabular}

SBP, sugar-beet pulp; DM, dry matter; ME, metabolizable energy.

Na levels were determined by flame photometry (Corning 400 flame photometer).

\section{Experimental}

Each experiment was of Latin Square design, with one or two replicates, depending on the number of cows available and the number of treatments used, except Expts $2 b$ and $3 b$ in which five cows were given each of four treatments. Treatments were applied for $3 \mathrm{~h}$, starting at approximately 11.00 hours, when fresh forage was offered. VFA salts for infusion were dissolved in 4.5 litres warm water and pumped into the rumen at a constant rate over $3 \mathrm{~h}$ via a $300 \mathrm{~mm}$ long nylon tube $(4 \mathrm{~mm}$ i.d., $6 \mathrm{~mm}$ o.d.) inserted through the cannula. Samples of rumen fluid were taken regularly over $5 \mathrm{~h}$ for the analysis of VFA and $\mathrm{Na}$. The samples were taken through sampling tubes placed inside the rumen through the cannula. The samplers were made of $700 \mathrm{~mm}$ long nylon tubing $(4 \mathrm{~mm}$ i.d., $6 \mathrm{~mm}$ o.d.) weighted with a piece of stainless steel (approximately $300 \mathrm{~g}$ ) attached to the end. Several $5 \mathrm{~mm}$ holes were drilled in the weighted end of the tubing and covered with fine nylon cloth to prevent blockage by particles. Samples were stored at $-20^{\circ}$ for subsequent analysis. When hay was fed the samples were taken at $30 \mathrm{~min}$ intervals from just before the start of infusion until $2 \mathrm{~h}$ after the end of infusion. With silage, sampling was hourly with an additional sample $30 \mathrm{~min}$ after the start of infusion. The $\mathrm{pH}$ of rumen fluid was measured immediately after collecting each sample. Food intakes were measured by weighing the refusals 3 and $5 \mathrm{~h}$ after the start of treatment. At least $2 \mathrm{~d}$ elapsed between successive treatments.

Expts $1 \mathrm{a}$ and $1 \mathrm{~b}$ involved infusion of sodium acetate with hay or silage respectively as the forage feed. Propionate was infused in Expts $2 \mathrm{a}$ and $2 \mathrm{~b}$ and balloon distension was applied in Expts $3 a$ and 3b; again, hay or silage were offered. Details of the experiments are shown in Table 2.

\section{Statistical analysis}

The data were analysed in two ways. Analysis of variance was performed using treatments, animals and days as factors using the General Linear Models procedure (Statistical Analysis Systems, 1985). To analyse the relationships between the level of each treatment and the response, regression analysis was used. 


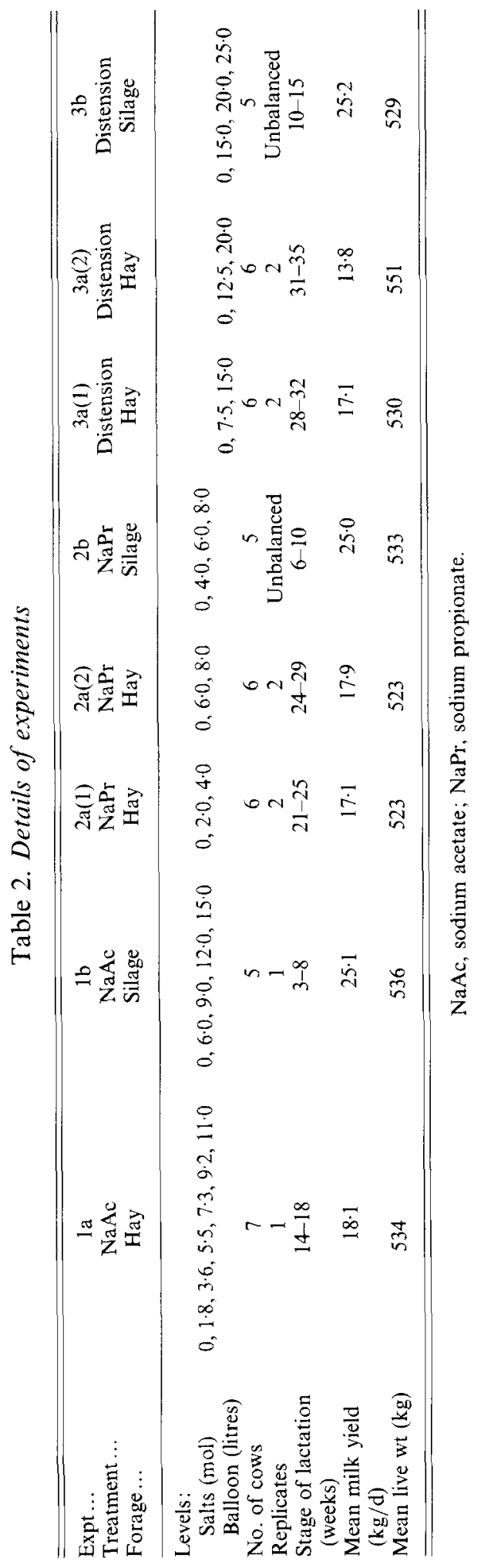


The relationships are expressed as:

$$
Y=a+b(\mathrm{SE}) X, \quad\left(r^{2} \quad ; P \quad\right)
$$

where $Y$ is DM intake ( $\mathrm{kg} / 3 \mathrm{~h}$ unless otherwise stated), $X$ is, for example, level of treatment, $a$ is the intercept, $b$ is the regression slope, $r^{2}$ is the proportion of variation in $Y$ associated with variation in $X$; in some cases the $r^{2}$ values are also given when effects due to animal and day are removed, $P$ is the probability that $b$ is different from zero. In all cases the possibility of curvilinearity was investigated by checking for both quadratic and semilogarithmic effects but in no case was the improvement of fit over the linear equation significant.

\section{RESULTS \\ Expt la}

Voluntary hay intake. Rates of infusion of sodium acetate above $5.5 \mathrm{~mol} / 3 \mathrm{~h}$ significantly depressed hay intake (Table 3 ) and there was a significant negative regression between rate of infusion of sodium acetate $(X, \mathrm{~mol})$ and hay intake $(Y, \mathrm{~kg})$ during the $3 \mathrm{~h}$ treatment period:

$$
Y=2.85-0.085(\operatorname{se} 0.024) X, \quad\left(r^{2} 0.66 ; P<0.05\right) .
$$

Rumen fluid $p H$. The $\mathrm{pH}$ of rumen fluid was unaffected by the infusions, mean values being within the range $6.4-6.7$ at all times.

Rumen fluid VFA concentrations. Infusion of sodium acetate significantly increased rumen acetate concentrations from $54 \mathrm{mmol} / 1$ for water to a maximum of $178 \mathrm{mmol} / \mathrm{l}$ $(P<0.05)$ for $11 \mathrm{~mol}$ acetate. Rumen fluid acetate concentration was significantly related to the dose of acetate infused at each sampling time from $1 \mathrm{~h}$ after the start of infusion to the last sample $2 \mathrm{~h}$ after the end of infusion. Rumen fluid acetate concentrations increased rapidly by the end of the first hour of infusion of acetate then decreased gradually towards the end of infusion and after the end of infusion remained significantly higher than the control values (Table 3$)$. Mean rumen fluid acetate concentration $(X, \mathrm{mmol} / \mathrm{l})$ was negatively correlated with hay intake $(Y ; \mathrm{kg} \mathrm{DM} / 3 \mathrm{~h})$ during the treatment period:

$$
Y=3 \cdot 16-0.007 \text { (SE 0.003) } X, \quad\left(r^{2} 0.59, P<0.05\right) \text {. }
$$

Rumen propionate and butyrate concentrations averaged 16.4 and $13.2 \mathrm{mmol} / \mathrm{l}$ respectively, and were unaffected by acetate infusions at all times.

Rumen fluid sodium concentrations. During the $0-3 \mathrm{~h}$ period concentrations significantly increased with the highest two rates of infusion (Table 3). Mean rumen fluid $\mathrm{Na}(X$, $\mathrm{mmol} / \mathrm{l})$ correlated significantly and negatively with hay intake $(Y, \mathrm{~kg} \mathrm{DM} / 3 \mathrm{~h})$ during the $0-3 \mathrm{~h}$ period,

$$
Y=3 \cdot 26-0 \cdot 005\left(\text { SE 0.0018) } X, \quad\left(r^{2} 0 \cdot 76, P<0 \cdot 05\right)\right. \text {. }
$$

Expt $1 b$

Voluntary silage intake. Silage intakes are shown in Table 4. There was a significant negative effect of 12 and $15 \mathrm{~mol}$ sodium acetate infusions on silage intake during the $3 \mathrm{~h}$ periods. These treatments also had a significant carry-over effect on intake during the $2 \mathrm{~h}$ post infusion.

Regression of silage DM intake during the $3 \mathrm{~h}$ treatment period $(Y, \mathrm{~kg})$ on the level of sodium acetate infused $(X, \mathrm{~mol})$ yielded the following equation:

$$
Y=2 \cdot 25-0.07(\mathrm{SE} 0.016) X, \quad\left(r^{2} 0.86 ; P<0.05\right) .
$$

The depression during the $2 \mathrm{~h}$ after the end of infusion was also significant:

$$
Y=1.32-0.06(\text { SE } 0.022) X, \quad\left(r^{2} 0.70, P<0.05\right) \text {. }
$$




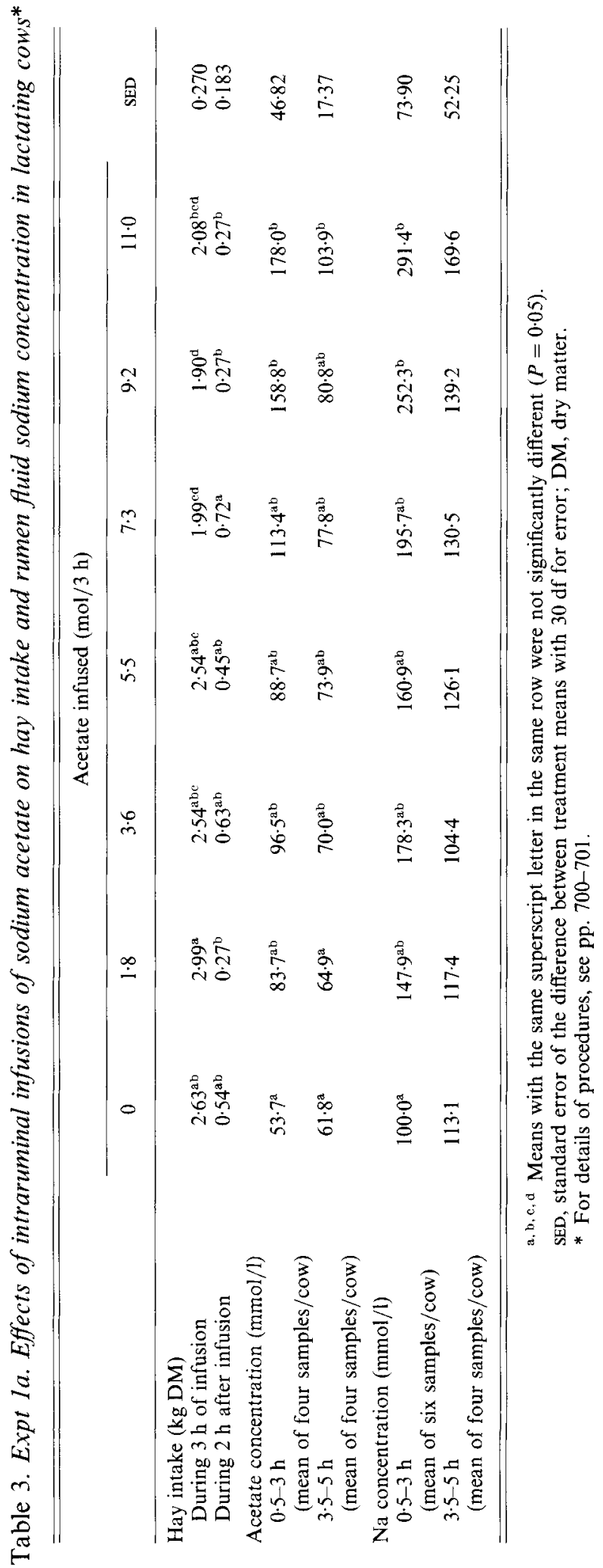


Table 4. Expt 1b. Effects of intraruminal infusions of sodium acetate on silage intake and rumen fluid sodium concentrations in lactating cows*

\begin{tabular}{|c|c|c|c|c|c|c|}
\hline & \multicolumn{5}{|c|}{ Acetate infused $(\mathrm{mol} / 3 \mathrm{~h})$} & \multirow[b]{2}{*}{ SED } \\
\hline & 0 & 6 & 9 & 12 & 15 & \\
\hline \multicolumn{7}{|l|}{ Silage intake (kg DM) } \\
\hline During $3 \mathrm{~h}$ of infusion & $2 \cdot 1^{\mathrm{a}}$ & $2 \cdot 0^{\mathrm{a}}$ & $1 \cdot 8^{\mathrm{ab}}$ & $1.3^{\text {be }}$ & $1 \cdot 1^{c}$ & 0.28 \\
\hline During $2 \mathrm{~h}$ after infusion & $1 \cdot 1^{\mathrm{a}}$ & $1 \cdot 3^{\mathrm{a}}$ & $0 \cdot 9^{\mathrm{ab}}$ & $0 \cdot 6^{\mathrm{ab}}$ & $0.3^{\mathrm{b}}$ & $0 \cdot 30$ \\
\hline \multicolumn{7}{|l|}{ Acetate concentrations $(\mathrm{mmol} / \mathrm{l})$} \\
\hline $\begin{array}{l}0.5-3 \mathrm{~h} \\
\text { (mean of four samples/cow) }\end{array}$ & $42 \cdot 3^{\mathrm{a}}$ & $74 \cdot 6^{\mathrm{b}}$ & $75 \cdot 8^{\mathrm{b}}$ & $93.5^{\text {bc }}$ & $96 \cdot 9^{c}$ & $8 \cdot 97$ \\
\hline $\begin{array}{l}\text { 4-5 h } \\
\text { (mean of two samples/cow) }\end{array}$ & $42 \cdot 0^{2}$ & $55 \cdot 6^{\mathrm{b}}$ & $64 \cdot 4^{\mathrm{e}}$ & $76 \cdot 1^{\mathrm{d}}$ & $76 \cdot 8^{d}$ & 3.62 \\
\hline \multicolumn{7}{|l|}{$\mathrm{Na}$ concentrations $(\mathrm{mmol} / \mathrm{l})$} \\
\hline $\begin{array}{l}0.5-3 \mathrm{~h} \\
\text { (mean of four samples/cow) }\end{array}$ & $89 \cdot 0^{\mathrm{b}}$ & $138 \cdot 9^{\mathrm{ab}}$ & $131 \cdot 2^{a \mathrm{D}}$ & $163 \cdot 0^{\mathrm{a}}$ & $197 \cdot 5^{\mathrm{a}}$ & $30 \cdot 05$ \\
\hline $\begin{array}{l}\text { 4-5 h } \\
\text { (mean of two samples/cow) }\end{array}$ & $74 \cdot 0^{\mathrm{d}}$ & $99 \cdot 3^{c}$ & $117 \cdot 8^{\mathrm{bc}}$ & $125 \cdot 1^{\mathrm{ab}}$ & $138 \cdot 5^{\mathrm{a}}$ & $9 \cdot 8$ \\
\hline
\end{tabular}

a.b,c.d Means with the same superscript letter in the same row were not significantly different $(P=0 \cdot 05)$. SED, standard error of the difference between treatment means with $12 \mathrm{df}$ for error; DM, dry matter.

* For details of procedures, see pp. 700-701.

Table 5. Expt 2a. Effect of intraruminal infusions of sodium propionate on hay intake and rumen fluid sodium concentrations in lactating cows*

\begin{tabular}{|c|c|c|c|c|c|c|c|c|}
\hline \multirow[b]{2}{*}{ Propionate infused (mol/ $/ 3 \mathrm{~h}$ ) } & \multicolumn{4}{|c|}{ Trial 1} & \multicolumn{4}{|c|}{ Trial 2} \\
\hline & 0 & 2 & 4 & SED & 0 & 6 & 8 & SED \\
\hline \multicolumn{9}{|l|}{ Hay intake (kg DM) } \\
\hline During $3 \mathrm{~h}$ of infusion & $2 \cdot 7$ & $2 \cdot 2$ & $2 \cdot 2$ & $0 \cdot 29$ & 1.7 & 1.0 & 1.5 & $0 \cdot 70$ \\
\hline During $2 \mathrm{~h}$ after infusion & 0.7 & $0 \cdot 5$ & 0.6 & $0 \cdot 20$ & $0 \cdot 7$ & 0.4 & $0 \cdot 3$ & $0 \cdot 20$ \\
\hline \multicolumn{9}{|l|}{ Propionate concentration (mmol/l) } \\
\hline $\begin{array}{l}0.5-3 \mathrm{~h} \\
\text { (mean of six samples/cow) }\end{array}$ & $17 \cdot 1^{a}$ & $26 \cdot 4^{\mathrm{ab}}$ & $44 \cdot 1^{\mathrm{c}}$ & $5 \cdot 8$ & $16 \cdot 7^{\mathrm{d}}$ & $43 \cdot 4^{\mathrm{de}}$ & $67.6^{\mathrm{e}}$ & $17 \cdot 06$ \\
\hline $\begin{array}{l}3 \cdot 5-5 \mathrm{~h} \\
\text { (mean of four sampies/cow) }\end{array}$ & $18 \cdot 3^{\mathrm{a}}$ & $22 \cdot 0^{\mathrm{b}}$ & $29 \cdot 5^{\mathrm{c}}$ & $1 \cdot 18$ & $17 \cdot 2^{\mathrm{d}}$ & $32 \cdot 8^{\mathrm{e}}$ & $43 \cdot 9^{e}$ & $4 \cdot 54$ \\
\hline \multicolumn{9}{|l|}{$\mathrm{Na}$ concentration $(\mathrm{mmol} / \mathrm{l})$} \\
\hline $\begin{array}{l}0.5-3 \mathrm{~h} \\
\text { (mean of six samples) }\end{array}$ & $107 \cdot 4^{\mathrm{a}}$ & $118 \cdot 3^{\mathrm{b}}$ & $133 \cdot 1^{\mathrm{e}}$ & $3 \cdot 48$ & $96 \cdot 2^{d}$ & $125 \cdot 7^{\mathrm{e}}$ & $151 \cdot 9^{f}$ & 9.06 \\
\hline $\begin{array}{l}3.5-5 \mathrm{~h} \\
\text { (mean of four samples/cow) }\end{array}$ & $105 \cdot 4^{a}$ & $112 \cdot 8^{b}$ & $117.9^{\mathrm{b}}$ & $2 \cdot 17$ & $102 \cdot 7^{\mathrm{d}}$ & $109 \cdot 2^{d}$ & $1349^{\mathrm{e}}$ & 6.09 \\
\hline
\end{tabular}

a. h.c,d,e,f Means with the same superseript letter in the same row were not significantly different $(P=0.05)$. SED, standard error of the difference between treatment means with 5 df for error for each trial; DM, dry matter.

* For details of procedures, see pp. 700-701.

Rumen fluid $\mathrm{pH}$. There was no effect of sodium acetate infusions on the $\mathrm{pH}$ of rumen fluid which remained within the range $6 \cdot 7-7 \cdot 0$.

Rumen fluid VFA. The concentration of acetate in rumen fluid was increased by acetate infusions during the $0-3 \mathrm{~h}$ period compared with the control (Table 4). Mean acetate concentration increased from $42 \mathrm{mmol} / \mathrm{l}$ (control) to $97 \mathrm{mmol} / 1$ with the $15 \mathrm{~mol}$ treatment $(P<0.05)$ and during the post-infusion period these levels remained significantly higher 
than the control levels $(42 \mathrm{mmol} / 1$ v. $77 \mathrm{mmol} / \mathrm{l} ; P<0.01)$. By the end of $2 \mathrm{~h}$ after infusions, the level of acetate remained significantly higher than the control for all treatments. Silage intake $(Y ; \mathrm{kg} \mathrm{DM} / 3 \mathrm{~h})$ was negatively correlated with mean acetate concentration $(X ; \mathrm{mmol} / \mathrm{l})$ in rumen fluid during the infusion period:

$$
Y=3.02-0.018(\text { SE } 0.0057) X, \quad\left(r^{2} 0.77 ; P<0.05\right) \text {. }
$$

There was no effect of treatment on the concentration of propionate or butyrate which averaged 15.6 and $8.2 \mathrm{mmol} / 1$ respectively.

Rumen fluid sodium. Mean rumen fluid $\mathrm{Na}$ increased significantly from $89 \mathrm{mmol} / \mathrm{l}$ with water infusion to $198 \mathrm{mmol} / 1(P<0.05)$ during the $3 \mathrm{~h}$ infusion of 15 mol sodium acetate (Table 4). After the end of infusion, $\mathrm{Na}$ in rumen fluid declined slowly towards the control value. The correlation between rumen fluid $\mathrm{Na}$ level and amount of sodium acetate infused was highly significant at all times. There was a significant correlation between $\mathrm{Na}$ concentration in rumen fluid $(X ; \mathrm{mmol} / 1)$ and silage intake $(Y ; \mathrm{kg} \mathrm{DM} / 3 \mathrm{~h})$ during the infusion period:

$$
Y=3.10-0.01(\text { SE } 0.0025) X, \quad\left(r^{2} 0.83 ; P<0.01\right) \text {. }
$$

\section{Expt $2 a$}

Voluntary hay intake. Mean intakes of hay during the infusions of sodium propionate and during $2 \mathrm{~h}$ after infusion are given in Table 5 .

Regression analysis of the data from trial 1 showed no significant relationship between sodium propionate infused $(X ; \mathrm{mol} / 3 \mathrm{~h})$ and hay intake $(Y ; \mathrm{kg} \mathrm{DM} / 3 \mathrm{~h})$ :

$$
Y=2.61-0.13 \text { (SE 0.072) } X, \quad\left(r^{2} 0.5 ;\right. \text { not significant (NS)). }
$$

However, when between-cow differences were accounted for there was a significant relationship $\left(r^{2} 0.89 ; P<0.05\right)$.

For trial 2 the equation was:

$$
Y=1.62-0.046(\mathrm{SE} 0.0733) X, \quad\left(r^{2} 0.28 ; \mathrm{NS}\right) .
$$

Rumen fluid $\mathrm{pH}$. The $\mathrm{pH}$ of rumen fluid was unaffected by propionate infusion in trials 1 and 2.

Rumen fluid short-chain fatty acids. Infusion of sodium propionate at the higher rate increased rumen fluid propionate significantly $(P<0.05)$ from a control value of 17 to $44 \mathrm{mmol} / 1$ (trial 1) and from 17 to $68 \mathrm{mmol} / \mathrm{l}$ (trial 2) during the $3 \mathrm{~h}$ infusion periods (Table 5 ). During the post-infusion period, rumen fluid propionate remained significantly higher when propionate was infused, compared with water, in both trials. For neither trial was there a significant relationship between hay intake $(Y ; \mathrm{kg} \mathrm{DM} / 3 \mathrm{~h})$ and mean rumen fluid propionate concentration during the infusion period $(X ; \mathrm{mmol} / 1)$.

Rumen fluid sodium levels. Infusions of 4 and 8 mol sodium propionate in trials 1 and 2 respectively increased $\mathrm{Na}$ levels in rumen fluid significantly $(P<0.05)$ during the infusion periods (Table 5). These levels remained higher $(P<0.05)$ than those of the control treatments during the $2 \mathrm{~h}$ period post infusion. There was no significant relationship between mean rumen fluid $\mathrm{Na}$ levels $(X ; \mathrm{mmol} / \mathrm{l})$ and hay intake during the infusions ( $Y$; $\mathrm{kg} \mathrm{DM} / 3 \mathrm{~h}$ ) for either trial.

\section{Expt $2 b$}

Voluntary silage intake. Infusions of 4,6 and 8 mol sodium propionate caused significant reductions in silage intake (Table 6). The relationship between the amount of sodium propionate infused $(X ; \mathrm{mol} / 3 \mathrm{~h})$ and the weight of silage DM eaten during the infusion ( $Y$; $\mathrm{kg} \mathrm{DM} / 3 \mathrm{~h}$ ) was negative and significant:

$$
Y=2.09-0.14(\text { SE } 0.064) X, \quad\left(r^{2} 0.99 ; P<0.001\right) \text {. }
$$


Table 6. Expt 2b. Effects of intraruminal infusions of sodium propionate on silage intake and rumen fluid sodium concentrations in lactating cows*

\begin{tabular}{|c|c|c|c|c|c|}
\hline & \multicolumn{4}{|c|}{ Propionate infused $(\mathrm{mol} / 3 \mathrm{~h})$} & \multirow[b]{2}{*}{ SED } \\
\hline & 0 & 4 & 6 & 8 & \\
\hline \multicolumn{6}{|l|}{ Silage intake (kg DM) } \\
\hline During $3 \mathrm{~h}$ of infusion & $2 \cdot 1^{\mathrm{a}}$ & $1 \cdot 5^{\mathrm{h}}$ & $1 \cdot 3^{\mathrm{bc}}$ & $1 \cdot 0^{c}$ & $0 \cdot 17$ \\
\hline During $2 \mathrm{~h}$ after infusion & $0 \cdot 8^{\mathrm{ab}}$ & $1 \cdot 1^{a}$ & $0 \cdot 8^{\text {an }}$ & $0.5^{\mathrm{h}}$ & $0 \cdot 17$ \\
\hline \multicolumn{6}{|l|}{ Propionate concentrations ( $\mathrm{mmol} / \mathrm{l})$} \\
\hline $\begin{array}{l}0.5-3 \mathrm{~h} \\
\text { (mean of four samples/cow) }\end{array}$ & $14 \cdot 4^{\mathrm{a}}$ & $37 \cdot 8^{\mathrm{b}}$ & $45 \cdot 0^{\mathrm{bc}}$ & $53 \cdot 9^{\circ}$ & $5 \cdot 58$ \\
\hline $\begin{array}{l}45 \mathrm{~h} \\
\text { (mean of two samples/cow) }\end{array}$ & $14 \cdot 4^{\mathrm{u}}$ & $33 \cdot 1^{b}$ & $41 \cdot 3^{\mathrm{bc}}$ & $48 \cdot 4^{c}$ & 3.92 \\
\hline \multicolumn{6}{|l|}{ Na concentrations (mmol/1) } \\
\hline $\begin{array}{l}0.5-3 \mathrm{~h} \\
\text { (mean of four samples/cow) }\end{array}$ & $78 \cdot 7^{\circ}$ & $108 \cdot 4^{\mathrm{bc}}$ & $123 \cdot 0^{b}$ & $175 \cdot 8^{\mathrm{a}}$ & $21 \cdot 54$ \\
\hline $\begin{array}{l}\text { 4-5 h } \\
\text { (mean of two samples/cow) }\end{array}$ & $86 \cdot 0^{c}$ & $91 \cdot 6^{\mathrm{bc}}$ & $106 \cdot 6^{\mathrm{ab}}$ & $121 \cdot 3^{a}$ & $7 \cdot 67$ \\
\hline
\end{tabular}

a. b.e: Means with the same superscript letter in the same row were not significantly different $(P=0 \cdot 05)$. SED, standard error of the difference between treatment means with $8 \mathrm{df}$ for error; DM, dry matter.

* For details of procedures, see pp. 700-701.

Rumen fluid $p H$. This was unaffected by sodium propionate infusions, remaining within the range $6 \cdot 2-6 \cdot 5$.

Rumen fluid $V F A$. Infusion of sodium propionate significantly increased rumen fluid propionate concentrations during the infusion period (Table 6). The treatment means differed significantly $(P<0 \cdot 05)$ from the control for all levels of infusion. During the $2 \mathrm{~h}$ after the end of infusions propionate concentrations remained significantly higher than the control for each treatment. Mean propionate concentration in rumen fluid $(X ; \mathrm{mmol} / \mathrm{l})$ was significantly negatively correlated with silage intake during the infusion period $(Y ; \mathrm{kg}$ $\mathrm{DM} / 3 \mathrm{~h})$ :

$$
Y=2.51-0.027(\operatorname{SE} 0.0012) X, \quad\left(r^{2} 0.99 ; P<0.001\right) .
$$

Rumen fluid sodium. Na levels in rumen fluid were increased for the highest rate of infusion of sodium propionate compared with control $(P<0.05)$ during the $3 \mathrm{~h}$ infusion period (Table 6), and these levels remained significantly higher than the control levels during the $2 \mathrm{~h}$ period post infusion. Mean Na levels were positively correlated with the level of sodium propionate infusion during the $0-3 \mathrm{~h}\left(r^{2} 0.61 ; P=0.004\right.$; estimated $\left.\mathrm{df} 11\right)$ and $3-5 \mathrm{~h}\left(r^{2}\right.$ $0.72 ; P=0.003$; estimated df 11$)$ periods. Rumen $\mathrm{Na}$ concentrations $(X ; \mathrm{mmol} / \mathrm{l})$ and silage intake during the infusion period $(Y ; \mathrm{kg} \mathrm{DM} / 3 \mathrm{~h})$ were significantly negatively correlated:

$$
Y=2 \cdot 78-0 \cdot 011(\text { SE } 0 \cdot 0028) X, \quad\left(r^{2} 0 \cdot 88 ; P<0 \cdot 05\right) \text {. }
$$

\section{Expt $3 a$}

Voluntary hay intake. Mean intakes are shown in Table 7. In both trials there were negative relationships between the volume of water in the balloon $(X$; litres) and the weight of hay eaten during the $3 \mathrm{~h}$ period of distension $(Y ; \mathrm{kg})$ :

$$
\begin{array}{ll}
\text { trial 1: } Y=2 \cdot 36-0.067(\operatorname{SE} 0 \cdot 0308) X, & \left(r^{2} 0 \cdot 82 ; \mathrm{NS}\right) . \\
\text { trial } 2: Y=5 \cdot 14-0.065(\operatorname{SE} 0.0325) X, & \left(r^{2} 0 \cdot 80 ; \mathrm{NS}\right) .
\end{array}
$$


Table 7. Expt 3a. Effects of inflation of a balloon in the rumen on hay intake by lactating cows*

\begin{tabular}{|c|c|c|c|c|c|c|c|c|}
\hline \multirow[b]{2}{*}{$\begin{array}{l}\text { Volume of water in balloon } \\
\text { (litres)... }\end{array}$} & \multicolumn{4}{|c|}{ Trial 1} & \multicolumn{4}{|c|}{ Trial 2} \\
\hline & 0 & 7.5 & 15 & SED & 0 & 12.5 & 20 & SED \\
\hline \multicolumn{9}{|l|}{ Hay intake (kg DM) } \\
\hline During $3 \mathrm{~h}$ inflation & $2 \cdot 5^{\mathrm{a}}$ & $1.6^{\mathrm{b}}$ & $1 \cdot 5^{\mathrm{b}}$ & 0.54 & $5 \cdot 0^{\mathrm{a}}$ & $4 \cdot 7^{\mathrm{a}}$ & $3 \cdot 6^{\mathrm{b}}$ & 0.31 \\
\hline During $2 \mathrm{~h}$ after deflation & 0.6 & 0.6 & 0.6 & 0.17 & $0 \cdot 6^{a}$ & $0.9^{\mathrm{ab}}$ & $1 \cdot 2^{\mathrm{b}}$ & 0.18 \\
\hline
\end{tabular}

a. $\mathrm{b}$ Means with the same superscript letter in the same row were not significantly different $(P=0.05)$. SED, standard error of the difference between treatment means with $5 \mathrm{df}$ for error in each trial; DM, dry matter.

* For details of procedures, see pp. 700-701.

Table 8. Expt 3b. Effects of inflation of a balloon in the rumen on silage intake by lactating cows*

\begin{tabular}{lccccc}
\hline \hline Volume of water in balloon (litres) $\ldots$ & 0 & 15 & 20 & 25 & SED \\
\hline Silage intake (kg DM) & & & & & \\
During 3 h inflation & $1 \cdot 6^{\mathrm{a}}$ & $1 \cdot 0^{\mathrm{b}}$ & $0 \cdot 9^{\mathrm{bc}}$ & $0 \cdot 8^{\mathrm{bc}}$ & $0 \cdot 16$ \\
During 2 h after deflation & $1 \cdot 3^{\mathrm{a}}$ & $1 \cdot 0^{\mathrm{ab}}$ & $0 \cdot 9^{\mathrm{b}}$ & $1 \cdot 0^{\mathrm{ab}}$ & $0 \cdot 13$ \\
\hline
\end{tabular}

a. $\mathrm{b}, \mathrm{c}$ Means with the same superscript letter in the same row were not significantly different $(P=0 \cdot 05)$ SED, standard error of the difference between treatment means with $8 \mathrm{df}$ for error; DM, dry matter.

* For details of procedures, see pp. 700-701.

In trial 2 there was significantly higher hay intake during the $2 \mathrm{~h}$ after treatment with 20 litres distension compared with 0 litre distension.

\section{Expt $3 b$}

There was a significant negative relationship between the degree of rumen distension with balloons $(X$; litres) and the weight of silage eaten $(Y ; \mathrm{kg})$ during the treatment period (Table 8):

$$
Y=1.55-0.033(\text { SE } 0.0023) X, \quad\left(r^{2} 0.99, P<0.01\right) .
$$

The slope of this relationship is not significantly different from those for hay (Expt $3 a$ ).

\section{DISCUSSION}

\section{Effects of infusions of sodium salts}

The results of Expts 1 and 2 show that infusions of sodium acetate or sodium propionate into the rumen of lactating cows caused a depression in hay or silage intake in a doserelated manner. The flux of acetate from visceral organs to the rest of the body in the lactating cow has been estimated to be about $2.3 \mathrm{~mol} / \mathrm{h}$ (Van de Walt, 1984), while the rate of uptake of propionate into the portal circulation is usually about one-third that of acetate (Stangassinger \& Geisecke, 1986). The lower rates of acetate or propionate infusion used in the present study were, therefore, within the physiological range of production but did not exert significant effects on intake, even though they were added to the VFA already being produced by the rumen. (It is worth noting at this point that the infusion would reduce 
microbial VFA production both directly and by reducing the intake of food.) High and unphysiological levels were required to depress intake significantly in the present study but these were included in the experiments to provide a more complete description of the nature of the dose-response relationship. Even though low levels of VFA salts had no significant effect there was a tendency for intake to be depressed and there were linear responses which suggested that the lower rates of infusion were having a real influence on intake, even if their effects did not individually reach statistical significance.

The mode of action of VFA salts on feed intake in ruminants is uncertain. Whereas it has been assumed that there are receptors for acetate in the rumen wall and for propionate in the liver (Baile \& Forbes, 1974; Anil \& Forbes, 1980), a strong case has been made for osmotic mechanisms (Ternouth \& Beattie, 1971; Carter \& Grovum, 1988). The experimental difficulty is that infusion of VFA lowers $\mathrm{pH}$, which inhibits rumen motility (Ash, 1959) and causes discomfort (M. H. Anil, J. N. Mbanya and J. M. Forbes, unpublished results). The use of $\mathrm{Na}$ salts of the VFA overcomes these problems but introduces difficulties for interpretation of the results because of the changes in $\mathrm{Na}$ concentration and osmolality of body fluids. Also, it is difficult to know whether the appropriate control should be no treatment, infusion of water or infusion of $\mathrm{NaCl}$. Our control treatment was water infusion which may have an intake-stimulating effect (Baile $e t$ al. 1969). $\mathrm{NaCl}$ has been used in some work and has a depressing effect on feed intake, sometimes (Grovum \& Bignell, 1989) but not always as great as that of the same molar quantity of sodium acetate (Mbanya, 1988; Engku Azahan \& Forbes, 1992).

However, the reduction in feed intake due to hyperosmolality of rumen fluid is greatly attenuated when the animal has free access to drinking water (Barrio et al. 1991) as did the cows in our experiments. In our subsequent work, feeding silage to lactating cows, we have found significant influences of rumen infusion of salts of VFA that could be attributed to increased rumen fluid osmolality (Forbes et al. 1993). Leek \& Harding (1975) described epithelial receptors in the rumen wall which were excited by acids to inhibit reflexly the primary cycle movements of the reticulo-rumen, but hyperosmotic solutions did not have a consistent effect. Thus, there is some doubt as to the importance of osmolality in stimulating rumen receptors.

If osmolality or $\mathrm{Na}$ were the major contributor to the effect of VFA salts on hay and silage intake then the effects of acetate and propionate should have been similar, and this is indeed the case. In Expt 1a; where sodium acetate was infused into the rumen of cows fed on hay and producing $18 \mathrm{~kg}$ milk/d, the slope of the regression line was $-0.08 \mathrm{~kg}$ $\mathrm{DM} / \mathrm{mol}$ infused, while for sodium propionate (Expt $2 \mathrm{a}$ ), when they were producing $17 \mathrm{~kg}$ $\mathrm{DM} / \mathrm{mol}$ infused, the slopes for the two trials were -0.12 and -0.05 , the differences being non-significant. For silage, when milk yields were $25 \mathrm{~kg} / \mathrm{d}$, the slope for acetate was $-0 \cdot 12$ and for propionate, $-0.14 \mathrm{~kg} \mathrm{DM} / \mathrm{mol}$ infused, again not significantly different. These results, therefore, do not refute the idea that two salts were acting through the same mechanism, i.e. osmolality.

There are also similarities between the relationships between the concentrations of the infused VFA in rumen fluid and intake, and that between $\mathrm{Na}$ concentration and intake, further suggesting that the effects of infusion are related to their molar strength and not necessarily to a specific chemical entity. It is possible, therefore, that the effects of the two VFA salts were mediated through the same osmosensitive mechanism.

A comparison of the effect of sodium acetate infusion on hay intake in Expt la with that on silage intake in Expt $1 \mathrm{~b}$ is confounded by the different stages of lactation. The slopes of the dose-response relationships were not significantly different, although the intercept was higher and the slope lower with hay compared with silage. The effect of increasing amounts of propionate on hay intake (Expt 2a) was also less than on silage intake (Expt 
2b). The fact that silage already contains some VFA is not an adequate explanation for this apparent difference, as this would be expected to affect the intercept rather than the slope of the relationship; nor would the lower levels of milk production in the hay experiment compared with that using silage readily explain the different slopes; higher nutrient demand for lactation should result in more rapid absorption of VFA and a smaller satiating effect within the rumen.

\section{Effects of distension}

Inflation of a balloon in the rumen caused decreases in the intakes of both hay (Expt 3a) and silage $(\operatorname{Exp} 3 \mathrm{~b})$. The depression in silage DM intake was half $(28 \mathrm{~g} \mathrm{DM} / \mathrm{l})$ that for hay (67 and $66 \mathrm{~g} \mathrm{DM} / \mathrm{l}$ ). However, the silage contained $230 \mathrm{~g} \mathrm{DM} / \mathrm{kg}$ so that the depression in fresh silage intake was $122 \mathrm{~g} / 1$ distension, a value more than double that for hay fresh matter. Of the water in silage, some is freely exchangeable with rumen fluid and does not contribute to its bulk while that trapped within cells is only released when cell walls are digested. Thus, the bulk of silage is somewhere between its fresh and dry matter contents. Consequently the depression in intake by balloon distension is greater than for hay when expressed in terms of fresh matter but less when expressed as DM.

Dairy cows offered silage of similar quality to that used here, and on a similar concentrate supplementation (Jackson et al. 1991) ate fifteen meals/d to achieve a total intake of $65 \mathrm{~kg}$ silage fresh matter/d. The average meal size was therefore $4.3 \mathrm{~kg}$ fresh matter, i.e. about $1.0 \mathrm{~kg} \mathrm{DM}$. Thus, the degree of distension applied in our experiments was greater than that likely to occur as a result of eating a typical meal, although limiting access to hay to $5 \mathrm{~h} / \mathrm{d}$ gave an increase in the total amount of digesta in the reticulo-rumen from $85.4 \mathrm{~kg}$ before feeding to $116.3 \mathrm{~kg}$ at the end of the feeding period (Freer \& Campling, 1963). The reduction in forage intake during distension was linearly related to the volume of water in the balloon so that it is likely that even a small balloon inflation would cause a real depression in intake. The failure by Carr \& Jacobson (1967) to depress hay intake significantly by adding up to $9 \mathrm{~kg}$ water to rubber bags in the rumen of cows could be attributed to the relatively small levels of distension. The same could be said for the work of Grovum (1979) when he distended the rumen of sheep by $800 \mathrm{ml}$, and in trial 1 of Expt $3 a$.

Distending the rumen depressed hay intake in our cows by $56 \mathrm{~g} \mathrm{DM} / 1$ water added in the balloon during the $3 \mathrm{~h}$ period. Campling \& Balch (1961) distended the rumen of nonlactating cows with about double the amount of water used in our studies and observed a very similar proportional decrease in intake of hay $(54 \mathrm{~g} \mathrm{DM} / \mathrm{kg}$ water added in the bladder). This is despite the fact that they subjected their cows to $10 \mathrm{~d}$ of continuous distension of the rumen and allowed them access to food for only $3-4 \mathrm{~h}$ daily.

\section{Conclusions}

The results reported previously have confirmed that sodium acetate, sodium propionate and distension, applied separately into the rumen, depress the intake of hay or silage in lactating cows in an approximately linear manner. It is likely that a major part of the effects of salts of VFA is by osmotic influences. The rate or level of treatment needed to induce a statistically significant reduction in voluntary intake was in each case greater than the likely changes during a spontaneous meal, but the significance of the regressions strongly suggests that the reductions at low levels of treatment are real, albeit small. None of these factors can, therefore, be considered to be acting independently to control voluntary intake of forage by cows.

It has been proposed that various satiety signals act additively to control voluntary intake (Forbes, 1986) so that the next stage should be to investigate the effects of 
combination of various factors, such as acetate, propionate and distension, simultaneously rather than individually. The results of the experiments reported here were used to provide a basis for the selection of treatments which individually do not reduce intake significantly to see whether when given together they have a significant effect (Mbanya et al. 1993); this proved to be the case. In addition, the alterations to normal physiological variables such as $\mathrm{Na}$ flux across the rumen epithelium and rumen fluid osmolality, which may be caused by the treatments such as those imposed in these experiments, need to be studied to elucidate further the control of voluntary food intake.

The financial support of the AFRC is gratefully acknowledged. J.N. M. was on study leave from the Institute of Animal Research, Cameroon. The authors thank Mr R. Harrison for his technical help throughout the experiments, Dr N. Jessop and Dr G. H. Smith for their invaluable advice on the estimation of VFA and the referee whose comments were most helpful.

\section{REFERENCES}

Anil, M. H. \& Forbes, J. M. (1980). Feeding in sheep during intraportal infusions of short-chain fatty acids and the effect of liver denervation. Journal of Physiology 298, 407-414.

Anil, M. H., Mbanya, J. N. \& Forbes, J. M. (1989). Depression of silage intake by the infusion of propionate into the rumen of the dairy cow. Animal Production 48, 639.

Anil, M. H., Mbanya, J. N., Symonds, H. W. \& Forbes, J. M. (1987). Dose-related effects on hay intake of acetate infused into the rumen of lactating cows. Proceedings of the Nutrition Society 46, 29A.

Ash, R. W. (1959). Inhibition and excitation of reticulo-ruminal contractions following the introduction of acids into the rumen and abomasum. Journal of Physiology 147, 58-73.

Baile, C. A. \& Forbes, J. M. (1974). Control of food intake and regulation of energy balance in ruminants. Physiological Reviews 54, 160-214.

Baile, C. A. \& Mayer, J. (1969). Depression of feed intake of goats by metabolites injected during meals. American Journal of Physiology 217, 1830-1836.

Baile, C. A., Mayer, J. \& McLaughlin, C. L. (1969). Feeding behavior of goats: ruminal distension, ingesta dilution and acetate concentration. American Journal of Physiology 217, 397-402.

Balch, C. C. \& Campling, R. C. (1962). Regulation of voluntary food intake in ruminants. Nutrition Abstracts and Reviews 32, 669-686.

Barrio, J. P., Bapat, S. \& Forbes, J. M. (1991). Proceedings of the Nutrition Society 50, 98A.

Bueno, L. (1975). Role of DL-lactic acid in the control of food intake in the sheep. Annales de Recherches Vétérinaires 6, 325-336.

Campling, R. C. (1964). Factors affecting voluntary intake of grass. Proceedings of the Nutrition Society $23,80-88$.

Campling, R. C. \& Balch, C. C. (1961). Factors affecting the voluntary intake of food by cows. 1. Preliminary observations on the effect, on the voluntary intake of hay, of changes in the amounts of reticulo-ruminal contents. British Journal of Nutrition 15, 523-530.

Carr, S. C. \& Jacobson, D. R. (1967). Intraruminal addition of mass or removal of rumen contents on voluntary intake of the bovine. Journal of Dairy Science 50, 1814-1818.

Carter, R. R. \& Grovum, W. L. (1988). Observations on how sodium chloride loading of the rumen depresses food intake in sheep. Proceedings of the Nutrition Society 47,155A.

Castle, M. E. (1983). Feeding high-quality silage. In Silage for Milk Production. NIRD, HRI Technical Bulletin no. 2, pp. 127-150. Shinfield: National Institute for Research in Dairying.

Clancy, M., Wangsness, P. J. \& Baumgardt, B. R. (1977). Effect of silage extract on voluntary intake, rumen fluid constituents, and rumen motility. Journal of Dairy Science 60, 580-590.

Dodsworth, T. L. (1954). Further studies on the fattening value of grass silage and on the effect of the dry-matter percentage of the diet on dry-matter intake in ruminants. Journal of Agricultural Science, Cambridge 44, 383-392.

Engku Azahan, E. A. \& Forbes, J. M. (1992). Effects of intraruminal infusions of sodium salts on selection of hay and concentrate foods by sheep. Appetite 18, 143-154.

Farhan, S. M. A. \& Thomas, P. C. (1978). The effect of partial neutralisation of formic acid silages with sodium bicarbonate on their voluntary intake by cattle and sheep. Journal of the British Grassland Society 33, $151-158$.

Forbes, J. M. (1986). The Voluntary Food Intake of Farm Animals. London: Butterworth.

Forbes, J. M., Mbanya, J. N. \& Anil, M. H. (1993). Comparisons of the effects on intraruminal infusions of sodium acetate and sodium chloride on silage intake by lactating cows. Appetite 19, 293-301.

Freer, M. \& Campling, R. C. (1963). Factors affecting the voluntary intake of food by cows. 5. The relationship between the voluntary intake of food, the amount of digesta in the reticulo-rumen and the rate of disappearance 
of digesta from the alimentary tract with diets of hay, dried grass or concentrates. British Journal of Nutrition 17, 79-88.

Gengler, W. R., Martz, F. A., Johnson, H. D., Krause, G. F. \& Hahn, L. (1970). Effect of temperature on food and water intake and rumen fermentation. Journal of Dairy Science 53, 434437.

Gordon, C. H., Derbyshire, J. C., Wiseman, H. G., Kane, E. \& Melin, C. G. (1961). Preservation and feeding value of alfalfa stored as hay, haylage and direct-cut silage. Journal of Dairy Science 44, 1299-1331.

Grovum, W. L. (1979). Factors affecting the voluntary intake of food by sheep. 2. The role of distension and tactile input from compartments of the stomach. British Journal of Nutrition 42, 425-426.

Grovum, W. L. \& Bignell, W. W. (1989). Results refuting volatile fatty acids per se as signals of satiety in ruminants. Proceedings of the Nutrition Society 48, 3A.

Jackson, D. A., Johnson, C. L. \& Forbes, J. M. (1991). The effect of compound composition and silage characteristics on silage intake, feeding behaviour, production of milk and live weight change in lactating dairy cows. Animal Production 52, 11-19.

Leek, B. F. \& Harding, R. H. (1975). Sensory nervous receptors in the ruminant stomach and the reflex control of reticulo-ruminal motility. In Digestion and Metabolism in the Ruminant, pp. 60-76 [I. W. McDonald and A. C. I. Warner, editors]. Armidale: University of New England.

McLeod, D. S., Wilkins, R. J. \& Raymond, W. F. (1970). The voluntary intake by sheep and cattle of silage differing in free-acid content. Journal of Agricultural Science, Cambridge 75, 311-319.

Mbanya, J. N. (1988). Effects of ruminal administration of acetate, propionate and distension on forage intake by dairy cows. PhD Thesis, University of Leeds.

Mbanya, J. N., Anil, M. H. \& Forbes, J. M. (1987). Rumen distension and depression of voluntary hay intake of the lactating cow. Proceedings of the 38th Annual Meeting of the European Association of Animal Production Lisbon, p. 424. Lisbon: EAAP.

Mbanya, J. N., Anil, M. H. \& Forbes, J. M. (1988). Effects of intraruminal infusions of sodium acetate on silage intake by dairy cows. Proceedings of the Nutrition Society 47, 177A.

Mbanya, J. N., Anil, M. H. \& Forbes, J. M. (1993). The voluntary intake of hay and silage by lactating cows in response to ruminal infusion of acetate or propionate, or both, with or without distension of the rumen by a balloon. British Journal of Nutrition 69, 713-720.

Ministry of Agriculture, Fisheries and Food (1986). The Analysis of Agricultural Materials. Reference Book 427. London: H.M. Stationery Office.

Moore, L. A., Thomas, J. W. \& Sykes, J. F. (1960). The acceptability of grass/legume silage by dairy cows. Proceedings of the 8th International Grassland Congress, pp. 701-704. Reading: University of Reading.

Neumark, H., Bondi, A. \& Volcani, R. (1964). Amines, aldehydes and keto-acids in silages and their effect on food intake by ruminants. Journal of the Science of Food and Agriculture 15, 487-492.

Phillip, L. E., Buchanan-Smith, J. G. \& Grovum, W. L. (1981). Effects of infusing the rumen with acetic acid and nitrogenous constituents in maize silage extracts on food intake, ruminal osmolality and blood acid-base balance in sheep. Journal of Agricultural Science, Cambridge 96, 429-438.

Stangassinger, M. \& Giesecke, D. (1986). Splanchnic metabolism of glucose and related energy substrates. In Control of Digestion and Metabolism in Ruminants, pp. 347-366 [L. P. Milligan, W. L. Grovum and A. Dobson, editors]. Englewood Cliffs, NJ: Prentice-Hall.

Statistical Analysis Systems (1985). SAS User's Guide, Statistics. Cary, NC: SAS Institute Inc.

Ternouth, J. H. \& Beattie, A. W. (1971). Studies of the food intake of sheep at a single meal. British Journal of Nutrition 25, 153-164.

Thomas, J. W., Moore, L. A., Okamoto, M. \& Sykes, J. F. (1961). A study of factors affecting rate of intake of heifers fed silage. Journal of Dairy Science 44, 1471-1483.

Van der Walt, J. G. (1984). Metabolic interactions of lipogenic precursors in the ruminant. In Herbivore Nutrition in the Tropics and Subtropics, pp. 571-593 [F. M. Gilchrist and R. I. Mackie, editors]. Craighall: Science Press. 